\title{
19
}

\section{Typology and efflorescence of early Islamic tomb and gravestone forms in South Sulawesi and Majene, West Sulawesi}

\author{
Rosmawati
}

\begin{abstract}
South Sulawesi province and the adjacent district of Majene in West Sulawesi are rich with the historic expressions of Islamic culture, in particular the many ancient tombs that are widespread across the area. The distribution of ancient tombs has had little empirical investigation, limiting our understanding of the cultural meaning of the form and content of these tombs. In order to expand our current knowledge of these memorial sites, as summarised in this paper, the author developed a typology of the tombs and gravestones located in the region with the aim of assisting further studies in the future. In terms of typology, the form of the gravestones in particular indicates influences of Malay culture (the Aceh type of gravestone) and Javanese culture (the Troloyo-Demak type of gravestone), as well as local cultural development (Bugis-Makasar tomb and gravestone types).
\end{abstract}

Keywords: South Sulawesi, Majene, graves, tombs, gravestones, Islamic culture

\section{Introduction}

An important archaeological legacy of early Islam in South Sulawesi is the cemeteries of kings, religious leaders and dukes (local authorities), buried with their relatives, friends, chiefs and closest slaves. These cemeteries are widespread across certain kabupaten or districts of South Sulawesi (i.e. former kingdoms whose territorial boundaries have persisted to the present day). These former kingdoms are represented in their cemetery complexes like those of the rulers of Gowa at Kale Gowa in Gowa District, the rulers of Tallok in Makassar city, the rulers of Sanrabone in Takalar District, the rulers of Binamu in Jeneponto District, the cemetery of the rulers of Luwu in Lokkoe (Palopo city), the rulers of Bone at Lala Bata Watampone and Makam Nagauleng, Jera Lompoe royal cemetery in Soppeng District, Tosora royal cemetery in Wajo District, Allakkuang cemetery in Sidrap District, Laiya cemetery in Enrekang District, and cemeteries for local rulers in Barru. Other cemetery complexes for the local elite include Makam Dea Daeng Lita in Bulukumba (18th century and later) and Makam Tandijalling in Enrekang (19th century and later) (Duli et al. 2013). Similar cemeteries have been recorded in Majene District in West Sulawesi (Figure 19.1). 


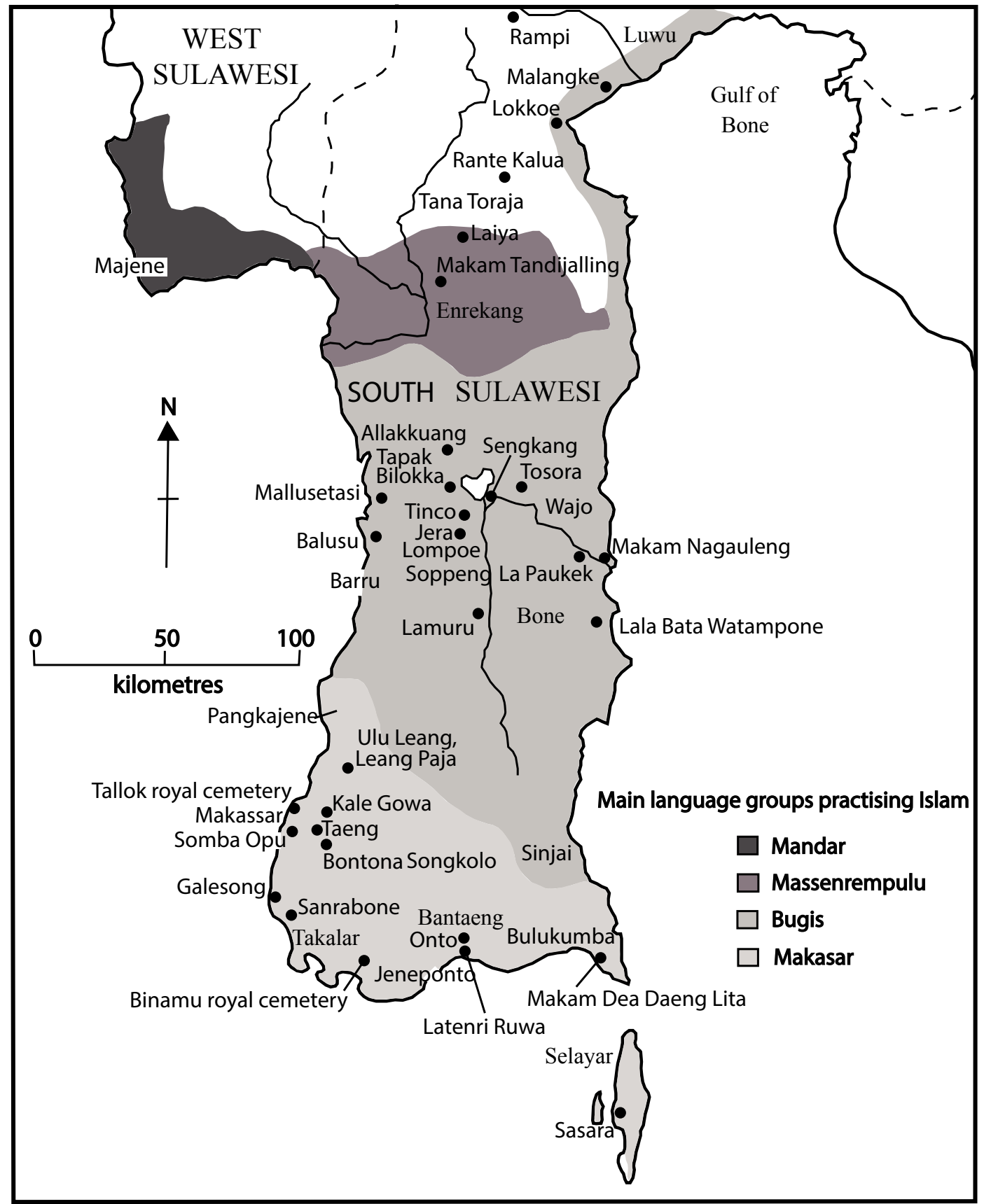

Figure 19.1: South and West Sulawesi-main language groups practising Islam and places mentioned in the text.

Sources: Masdoeki (1984, 1985a); Muttalib (1984); Makkullasse (1986); Bulbeck (1992); Duli et al. (2013); Hasanuddin (2015).

Functional interpretation of the tombs and their components is redundant as the function of tombs from prehistoric to present-day examples is clear. The relevant issues for archaeological study of the headstones and the graves are their style, shape and components, as well as the related geographic distribution both in coastal regions and the interior. In the majority of cases, analysis is restricted to the ornamental dimension, even if the philosophy behind the ornamental patterns cannot be determined (Santosa 1980:486; Marioga 1995:41). 
Research into Islamic archaeology in Indonesia is not new, and indeed can be traced back to 1907 in the coastal stretches of northern Aceh (Djajadiningrat 1911; Vink 1912). The development of this research can be seen in Tjandrasamita (2000), who compiled earlier scholars' research under the themes of Indonesian archaeology and history, Indonesian Islamic antiquities and Indonesia's historic sites. Tjandrasamita's (2009) posthumous synthesis structured research into Indonesia's Islamic archaeology in terms of Islam's relationship with cosmopolitan dynamics, local social dynamics in Indonesia, traditions of written works in Indonesia, and the shaping and inheritance of Indonesian cultural traditions. Research specifically directed at the history of Islam in South Sulawesi include Pelras (1985), whose approach integrated his broad knowledge of relevant historical texts with his extensive knowledge of South Sulawesi ethnography accumulated over several decades, and Suriada and Abbas (2003), whose approach focused on sources locally available in South Sulawesi.

A common theme (e.g. Tjandrasamita 2009; Sulistyo 2013) is the incorporation of pre-Islamic beliefs and rituals within Islamic practice during the expansion of Islam across Indonesia, including South Sulawesi after AD 1603. For instance, Pelras (1985) observed that many devout Muslims in South Sulawesi comfortably entertain non-Islamic notions such as beliefs in local spirits and the literal truth of the La Galigo (with its tales of how the world was populated by godly figures and their servants from the heavens and the underworld); they also venerate the regalia that the divine founders of South Sulawesi's historical kingdoms supposedly brought with them to pass onto future rulers, and uphold a tradition of transvestite priests (bissu) who have custody over the regalia and related aristocratic ceremonies. The archaeological documentation of syncretist Islam in Indonesia is a particular feature of Ambary's (1998) research. One component of his investigations involved the study of Islamic graveyards associated with historical (17th to early 20th century) aristocracy in South Sulawesi (Ambary 1985), a research program subsequently expanded by Duli et al. (2013).

The work by Duli et al. (2013) forms a basis for the present contribution, which develops on it in the following respects. First, the typology of graves and headstones developed there-which is an essential prerequisite for relating these Islamic mortuary monuments to the development of South Sulawesi's brand of syncretist Islam—is expanded here (see Appendix A). Second, the material culture associated with pre-Islamic mortuary practices and other rituals honouring the ancestors in South Sulawesi is covered, based on currently available evidence. This material culture was associated with a tradition of geometric and curvilinear decorations, which show stylistic overlap with the decorations found on South Sulawesi's gravestones. Third, changes in South Sulawesi graves and gravestones are placed in a historical context with reference to potential influences on South Sulawesi society from other Islamised regions.

\section{Pre-Islamic ritual material culture in South Sulawesi}

\section{Anthropomorphic representations}

Anthropomorphic representations are of interest for their presence in the 'Type D2' gravestones at some Islamic cemeteries in South and West Sulawesi (Figure A19.5), in apparent abrogation of the general Islamic proscription against portraying human figures as idols. They are a recurrent if not a dominant motif in the South Sulawesi pre-Islamic archaeological record that can be associated with Austronesian speakers, as the following examples show. 
Anthropomorphic rock art drawings are a notable component of the 'Austronesian Painting Tradition' documented in the Maros-Pangkep karsts and assumed to date to the last few thousand years (Oktaviana et al. 2016). These anthropomorphs were mainly rendered as stick figures and often in dynamic pose (Sumantri 1996), quite unlike any other pre-Islamic or Islamic anthropomorphic artworks in South Sulawesi.

Stone human statues similar to the Laiya anthropomorphic gravestones (Figure A19.5) are recorded as a feature of the northern highlands of South Sulawesi at Rante Kalua (Tana Toraja) and the Rampi District. These statues resemble the larger statues of the Bada, Besoa and Napu valleys of Central Sulawesi, where a rich tradition of sculpting megaliths (including massive stone jars called kalamba) is well documented. Contemporaneity of the Rampi human statues with their Central Sulawesi counterparts is indicated by three Accelerator Mass Spectrometry (AMS) determinations on charcoal, excavated near the base of one of the statues, which date to the early centuries AD (Hasanuddin 2015; Fakhri 2016).

Three bronzes considered to be locally produced during the 1st millennium AD or shortly after include anthropomorphic depictions. One is the unique 'Makassar flask', which is a large, swallowtail bronze axe with a human face similar to that on the human statues mentioned above (van der Hoop 1941:Fig. 54). The other two are seated figures of minor Buddhist deities found at Sasara, Selayar, which are interpreted as local imitations of East Java's Nganjuk style of Buddhist bronze statuettes (Caldwell and Nur 2005). Their Javanese imprint distinguishes them from Sulawesi's other anthropomorphic artworks, including the death masks of beaten gold that have occasionally been found covering the facial skeleton of late pre-Islamic burials in Makasar-speaking areas (Bougas 2007). On the other hand, their seated position marks a specific resemblance to the Binamu anthropomorphic gravestones (Figure A19.5).

Anthropomorphic pottery in mortuary contexts includes a terra cotta human head amongst the $98 \mathrm{~kg}$ of pottery associated with mortuary disposals dating to the 1 st millennium AD at Ulu Leang 2 in the Maros karsts (Andrews and Glover 1986; Flavel 1997). There are also human figurines of terra cotta looted from cemeteries in Bantaeng and Jeneponto in association with 13th-16th-century imported ceramics. Bougas $(1998,2007)$ interprets them as ancestor figures and suggests a specific link with the Binamu anthropomorphic gravestones, but more generally they reinforce the impression that, from time to time in the past, Austronesian-speaking artists in South Sulawesi have resorted to the use of human images.

\section{Standing stones}

Menhirs (tall standing stones) are often thought of as a major component of the South Sulawesi 'megalithic tradition', as is especially true of Tana Toraja where they were intimately associated with 'animist' mortuary feasts (Hasanuddin 2015). Within the peninsula, single menhirs are documented at Tapak Bilokka in Sidrap (Hasanuddin 2015), various Soppeng sites including Laleng Benteng and Bila (near Jera Lompoe) and Tinco (Kallupa et al. 1989), and at Kale Gowa (Bulbeck 1992). Multiple menhirs have been documented for Wajo sites including Sengkang, Sompoh (near Sengkang) and La Paukek, in the latter two cases associated with disturbed urnfields and surface scatters of imported ceramics dated between the 15th and 17th centuries (van Heekeren 1950; Bulbeck and Caldwell 2000). A late pre-Islamic antiquity is also indicated by local legends that associate the Kale Gowa menhir with the c. 14th-century foundation of Gowa, and the Laleng Benteng and Tinco examples with the c. 14th-century foundation of Soppeng; in the case of Tinco, supported by an abundance of c. 13th-17th-century ceramics on the site's surface (Kallupa et al. 1989) and three AMS determinations on excavated charcoal dating between the 13th and 15th-17th centuries (Hasanuddin 2015:309). These menhirs with late preIslamic credentials were a potential inspiration for the menhir (Type D12) Islamic gravestones

\section{terra australlis 48}


so widespread across the South Sulawesi peninsula (see Appendix A), even if menhir production may have 'taken off' with Islamisation. A case in point is the Ujung Islamic cemetery near Jera Lompoe, whose 84 menhir gravestones (plain and decorated), with an estimated age between the 17 th and 19th centuries, is the largest concentration recorded for Soppeng (Kallupa et al. 1989).

A similar situation may apply for South Sulawesi's lingga or phallic stones, which are often thought to reflect pre-Islamic Hinduist influence (Duli et al. 2013; Hasanuddin 2015). The cylindrical 'uncircumcised' variant, such as the 'male stones' heaped together with round 'female stones' at the Onto pre-Islamic ritual centre in Bantaeng (Bougas 2007), has no clear mortuary association. In contrast, the Type D11, phallic Islamic gravestones reveal a circumcised form (Figure A19.2), consistent with the importance of circumcision as an initiation ceremony for Muslim males.

\section{Mortuary practices}

Cremation of the remains of the deceased is suspected to reflect influence from Java where it is associated with the Hindu/Buddhist ideology that held sway prior to the widespread conversion to Islam across Java during the 16th century. Cremation is the only practice for handling corpses documented for the pre-Islamic Bugis who interred the ashes in large jars at cemeteries, such as the urn-fields mentioned above.

In the case of the Makasars, however, there appears to have been a change at around the 14th century from cremation/urn burial to inhumation of the deceased in an extended east-west position, accompanied by grave goods and sometimes placed in boat-shaped coffins. Bougas (2007) discusses the possibility that this change in burial practice reflects influence from the Samar-Bajau sea gypsies of the southern Philippine region, but also emphasises the significance of an east-west orientation in the context of the Makasar pre-Islamic worship of the sun. There is no documentation of any durable markers erected above the ground to mark Makasar pre-Islamic burial locations, but Masdoeki (1985a) and Bulbeck (1992) recorded a large number of graves in early Islamic Makasar graveyards oriented east-west rather than following the north-south orientation, which is orthodox for Indonesian Muslims (with the corpse placed on its side, facing Mecca). These east-west oriented graves could reflect Islamic-inspired marking of the graves of persons who had originally been buried according to the pre-Islamic tradition, or a syncretist blending of indigenous pre-Islamic and introduced Islamic beliefs.

\section{Non-anthropomorphic decorative designs}

The non-anthropomorphic component of the 'Austronesian Painting Tradition' (described above) consisted mainly of sketchy abstract compositions, blocky zoomorphs and representations of boats and other wooden material culture (Sumantri 1996). The incised designs recorded for Soppeng megaliths include a deer incorporated in a set of square panels and a composition of spoked wheels interpreted as possible cakras of Hindu/Buddhist inspiration (Hasanuddin 2015). None of these designs can be traced as influences on South and West Sulawesi Islamic art.

More promising is the 'Sa-Huynh Kalanay' earthenware pottery from several sites in the southern peninsula of South Sulawesi, dating approximately to the 1st millennium AD. These remarkably ornate assemblages predominantly involve horizontal translations of a wide variety of punctate and incised motifs along with a smaller component of triangular and rectangular mazes and curvilinear compositions. Most of the sites have mortuary associations, but the particularly ornate pottery at Batu Ejayya in Bantaeng evidently had non-mortuary ritual associations (Flavel 1997). The abstract designs on the Makassar flask may belong to the same decorative tradition, even though they include some motifs not yet recorded for pottery in South Sulawesi. 
Various 'Sa-Huynh Kalanay'-related designs can be found on Islamic gravestones in South Sulawesi (Table 19.1), although the floral representations that dominate these gravestones do not appear to have pre-Islamic precedents.

Table 19.1: Decorative designs on Islamic gravestones with Sa-Huynh Kalanay associations, South Sulawesi.

\begin{tabular}{|l|l|l|l|}
\hline Design & Gravestone type & Pre-Islamic object/assemblage & Reference \\
\hline Curvilinear maze & Crenulated gravestone (Figure A19.2)(a) & Batu Ejayya & Flavel 1997 \\
\hline Interlocking waves & D1, Jear Lompoe (Figure A19.5) & Leang Paja, Maros & Flavel 1997 \\
\hline Fern tendril scroll & D4, Binamu cemetery (Figure A19.5) & Makassar flask & van der Hoop 1941 \\
\hline Chevron translation & D4, Tosora (Figure A19.5) & Ulu Leang, Maros & Flavel 1997 \\
\hline Fretwork & D7, Jear Lompoe (Figure A19.5) & Leang Paja, Maros & Flavel 1997 \\
\hline
\end{tabular}

(a) A similar design is shown at the entrance to the tomb of Sultan Abdullah Muhiddin, Malangke (Chamshi-Pasha 2008).

\section{Architectural trends of ancient tombs and gravestones and their expansion in South and West Sulawesi}

By identifying the types, noting the inscriptions (including names and dates), associating the commemorated deceased with the available historical information from oral and textual sources, and recording the occurrences of the varying styles in the many ancient cemetery complexes of South and West Sulawesi, it is possible to delineate the flux of stylistic trends and the timeline of their appearance. Tables 19.2 and 19.3 present a diagnostic selection of grave and gravestone types for Islamic personages with approximately or exactly known burial date.

Table 19.2: Examples of graves and gravestones associated with Islamic personages of 17th-century burial date.

\begin{tabular}{|c|c|c|c|}
\hline Personage & Grave type & Gravestone type & Reference \\
\hline $\begin{array}{l}\text { La Tenri Ruwa, 11th Bone ruler, buried at Bantaeng } \\
\text { in } 1634\end{array}$ & D & AA (0thman Type C) & Muttalib 1980 \\
\hline $\begin{array}{l}\text { Sultan Abdullah Muhiddin, 2nd Muslim Luwuq } \\
\text { ruler, buried at Malangke in } 1636\end{array}$ & $\mathrm{~F}$ & D8 & Chamshi-Pasha 2008 \\
\hline $\begin{array}{l}\text { Sultan Awalul Islam, 7th Tallok ruler, buried at Kale } \\
\text { Gowa in } 1636\end{array}$ & $J / D^{*}$ & AA/AA (both 0thman Type C): & Duli et al. 2013 \\
\hline $\begin{array}{l}\text { Sultan Alauddin, 14th Gowa ruler, buried at Kale } \\
\text { Gowa in } 1639\end{array}$ & $J / D^{*}$ & AA/AA (0thman Types $\mathrm{H}$ and J): & Duli et al. 2013 \\
\hline $\begin{array}{l}\text { Tumenanga ri To'bana, buried near Sanrabone } \\
\text { in early } 17 \text { th century }\end{array}$ & E & D10 & Masdoeki 1985a \\
\hline Karaeng Katinting, buried at Tallok in 1650 & $\mathrm{E}$ & 08 & Bulbeck 1992 \\
\hline $\begin{array}{l}\text { Sultan Malikussaid, 15th Gowa ruler, buried at Kale } \\
\text { Gowa in } 1653\end{array}$ & $J / D^{*}$ & AA/AA (both 0thman Type C): & Duli et al. 2013 \\
\hline $\begin{array}{l}\text { Sultan Mudhaffar, 8th Tallok ruler, buried at Tallok } \\
\text { in } 1653\end{array}$ & $B$ & AA (Othman Type C) & $\begin{array}{l}\text { Masdoeki 1985b; } \\
\text { Bulbeck } 1992\end{array}$ \\
\hline $\begin{array}{l}\text { Sultan Mahmud, buried at Kale Gowa in mid-17th } \\
\text { century }\end{array}$ & A & Not recorded & Bulbeck 1992 \\
\hline $\begin{array}{l}\text { Sultan Hasanuddin, 16th Gowa ruler, buried at Kale } \\
\text { Gowa in } 1670\end{array}$ & $J / D^{*}$ & AA (Othman Type K)/D8* & Duli et al. 2013 \\
\hline $\begin{array}{l}\text { Sultan Amir Hamzah, 17th Gowa ruler, buried } \\
\text { at Kale Gowa in } 1674\end{array}$ & $J / D$ & AA (0thman Type C) & Duli et al. 2013 \\
\hline $\begin{array}{l}\text { We Tenri Kawareng, buried at Jera Lompoe in late } \\
\text { 17th century }\end{array}$ & $j$ & AA (0thman Type K) & Duli et al. 2013 \\
\hline
\end{tabular}




\begin{tabular}{|l|l|l|l|}
\hline Personage & Grave type & Gravestone type & Reference \\
\hline $\begin{array}{l}\text { Addatuang Sidenreng, buried at Jera Lompoe in } \\
\text { late 17th century }\end{array}$ & D & D12 & $\begin{array}{l}\text { Ambary 1985; } \\
\text { Muttalib 1984 }\end{array}$ \\
\hline $\begin{array}{l}\text { Sultan Muhammad Ali, 18th Gowa ruler, buried at } \\
\text { Kale Gowa in late 17th century }\end{array}$ & J/D* & AA (0thman Type K)/D8* & Duli et al. 2013 \\
\hline $\begin{array}{l}\text { La Tenri Bali Matinroe ri Datunna, 15th Soppeng } \\
\text { ruler, buried at Jera Lompoe in late 17th century }\end{array}$ & J & D9 & Muttalib 1984 \\
\hline $\begin{array}{l}\text { Karaeng Bungaya, buried at Taeng in mid-17th } \\
\text { century }\end{array}$ & I & D9 & $\begin{array}{l}\text { Figure A19.1, this } \\
\text { chapter }\end{array}$ \\
\hline $\begin{array}{l}\text { Karaeng Parang Parang, buried at Tallok in late } \\
\text { 17th century }\end{array}$ & C & Not recorded & $\begin{array}{l}\text { Bulbeck 1992; Trip } \\
\text { Advisor 2017 }\end{array}$ \\
\hline Gowa noble, buried at Somba 0pu in 1692 & D & D8 & Bulbeck 1992 \\
\hline
\end{tabular}

" Two paired gravestones: one pair with the grave inside the stepped terrace and the second pair on top of the stepped terrace.

Table 19.3: Examples of graves and gravestones associated with Islamic personages of approximately 18th-century burial date.

\begin{tabular}{|c|c|c|c|}
\hline Personage & Grave type & Gravestone type & Reference \\
\hline Syech Yusuf, buried at Kale Gowa in 1705 & A & D15 & Bulbeck 1992 \\
\hline La Cella, 5th Lamuru ruler, buried at Lamuru in 1710 & B & D3 & Duli et al. 2013 \\
\hline $\begin{array}{l}\text { Sultan Abdul Jalil, 19th Gowa ruler, buried at Kale } \\
\text { Gowa in } 1711\end{array}$ & $J / D$ & Not reported & Duli et al. 2013 \\
\hline $\begin{array}{l}\text { Sultan Alimuddin (16th Bone ruler) and two wives, } \\
\text { buried at Makam Nagauleng in early 18th century }\end{array}$ & Not reported & 012 & Duli et al. 2013 \\
\hline $\begin{array}{l}\text { La Mappa Poleonro Sultan Nuh., 28th Soppeng } \\
\text { ruler, buried at Jera Lompoe in late 18th century }\end{array}$ & $C$ & D11 & Muttalib 1984 \\
\hline $\begin{array}{l}\text { Datu Mari-Mari Guttu Patalo, buried at Jera Lompoe } \\
\text { in late 18th century }\end{array}$ & $G$ & D10 & Muttalib 1984 \\
\hline Sultan Sirajuddin, buried at Tallok in 1756 & D & B & $\begin{array}{l}\text { Masdoeki 1985b; } \\
\text { Bulbeck } 1992\end{array}$ \\
\hline $\begin{array}{l}\text { La Mappaware Petta Matinroe, 7th Lamuru ruler, } \\
\text { buried at Lamuru in 18th century }\end{array}$ & D & D9 & van Romondt 1985 \\
\hline $\begin{array}{l}\text { Tumenanga ri Masigini, buried at Sanrabone } \\
\text { in 18th century }\end{array}$ & A & B & Masdoeki 1985a \\
\hline $\begin{array}{l}\text { Karaeng Gosseya Bombang, buried at Binamu } \\
\text { in 18th century }\end{array}$ & D & AA (0thman Type A)/D2 & Bougas 2007 \\
\hline Raja Laiya, buried at Laiya in 18th century & $\mathrm{F}$ & D8 & Duli et al. 2013 \\
\hline $\begin{array}{l}\text { Sultan Saifuddin, buried at Tallok in late } \\
\text { 18th century }\end{array}$ & A & AA (0thman Type C)/C & Masdoeki 1985b \\
\hline Matinroa ri Lanna, buried at Galesong in 1809 & D & D8 & Masdoeki 1985a \\
\hline
\end{tabular}

The earliest styles of tombs (Table 19.2) include the terraced style (Type B) and stepped tomb (Type D), first appearing in the early 17 th century. These were usually associated with gravestones of the Aceh type (as defined by Othman 1988), reflecting Malay influence from Java. Further tomb styles that appeared by the early to mid-17th century, sometimes associated with Bugis-Makasar style gravestones (e.g. D8 and D10), include the standard (Type J), boatshaped (Type E), candi (Type F) and dome-covered styles (Type A). The candi-style tomb at Malangke is specifically linked to Hindu/Buddhist influence from Java by van Romondt (1985) and Chamshi-Pasha (2008). The boat-shaped tombs resemble the pre-Islamic Makasar boatshaped coffins in concept but not in design, as these Type E Islamic tombs are above-ground structures and also grander and more complex. Note that continuity of pre-Islamic iconography in the Bugis-Makasar gravestone types is probably stronger than indicated in Table 19.2: the kris 
handle style (D1) is locally associated with the 11th Soppeng ruler La Mata Esso, but he died shortly before Soppeng had accepted Islam (Ambary 1985); and the great majority of the menhir (D12) gravestones were erected for personages whose identities are no longer remembered (e.g. Kallupa et al. 1989).

The Type A dome-covered tomb does not have clear antecedents outside of Sulawesi and may be a local development. However, probably reflecting cultural influence from South Sulawesi, late 17th-century examples of this tomb type also occur on the island of Sumbawa (Noorduyn 1987). These include the graves of the Bima sultans Abdul Khair Sirajuddin (reigned 1640-1682), Nuruddin (reigned 1682-1687) and Jamaluddin (reigned 1687-1696), all of whom entered into marriage relationships during the 17 th century with the ruling lineages of Makassar (Bulbeck 1992).

The tomb styles mentioned above continued in use during the late 17th and the 18th centuries (Tables 19.2 and 19.3), but additional styles also began to emerge, such as wooden graves (Type I) and the traditional house style (Type C). Also during the 18th century, utilisation of the Demak-Troloyo gravestone type began, along with continued use of the Aceh and Bugis-Makasar gravestone types (now expanded to include D2, D3, D9, D10, D12 and D15), whereby the latter saw a continuation of pre-Islamic elements. The Demak-Troloyo gravestone type originated with the 15th-century conversion to Islam of the Hindu/Buddhist rulers of Majapahit in East Java (Tjandrasasmita 2009:76-77). Demak became a major centre of mystical Islam thought in the 18th century (Ricklefs 2008:60), which may have been the stimulus for the adoption of this gravestone type in South and West Sulawesi at this time.

Tombs are usually refined in their construction; they often have parallel siding and smooth finishing, and some even resemble the houses of the living. The majority of the tombs and gravestones were made from stone with the exception of two types, those made from wood (Type I) and tombs constructed from mounding dirt (Type L). The tombs were generally carved with a variety of ornamental embellishments during this early period. In later centuries, these tomb and gravestone types continued, but instead of stone, the builders used newer materials such as brick and cement for their construction (e.g. Bulbeck 1992).

The architecture of the graves displays an Islamic art style rooted in Indonesian culture as can be seen from the rich variety of ornaments on the graves, the gravestones and the tomb covers. In some cases, it seems to be in deliberate abrogation of the Islamic prohibition against the display of human or animal forms for worship. In order to retain their cultural artistic expression while conforming to the Islamic influence of the time, the artists included pre-Islamic forms (including the phallus and Hindu pagoda) alongside more acceptable Islamic decoration such as leaf-shaped motifs and calligraphic inscriptions of holy passages from the Koran (Duli et al. 2013). This syncretistic iconography occurs frequently in the ancient cemetery complexes of South and West Sulawesi.

Other common decorative patterns on the gravestones are of single emblems or fields that are rich in Islamic ornamental decorations. Their grave covers often contain various geometric (e.g. cross-hatched, meandering or rhomboid) and floral decorations (e.g. tendrils, leaves and herbs) on the roof and pillars, as well as medallions, spiralling leaves and calligraphy (Duli et al. 2013).

\section{Themes and conclusion}

Cultural evolution and changes in traditional customs are highly apparent with the development of and increased variability in the styles of the tombs and gravestones contained in the many ancient cemeteries of the provinces of South and West Sulawesi. The expression of this cultural 
change was highly variable, which was reflected in the grave markers themselves, producing a plethora of styles within the many types identified in this study. This diversity was likely inspired by the people who lived, worked, reigned, preached and died in each separate society-adding their own ideas and stylistic flare to the place where they laid their deceased relatives to rest.

The most significant influence was, of course, the introduction of Islam to the region. When external contacts came there, bringing with them the Islamic culture to introduce to the local people, a meeting of the two cultures occurred. The developing relationship of these very different cultures resulted in acculturation and the admixture of elements from both to produce each region's unique cultural identity. However, the process did not involve a passive blending of local pre-Islamic and introduced Islamic elements, but also generated new stylistic and religious elements that were not present with the parental cultures. Examples of this include the development of the dome-covered (Type A) tombs and boat-shaped (Type E) tombs as large aboveground structures, as well as certain Bugis-Makasar gravestone types (for instance, the D5, D6 and D10 types), which do not appear to have local pre-Islamic or external Islamic precedents.

Cultural contact and acculturation between the local prehistoric and Islamic cultures, along with influences from the Malays, the Javanese and the Europeans, occurred in stages over a lengthy period (Sulistyo 2013; Bulbeck et al., this volume). It is clear that during this early Islamic period, as part of the process of Islamisation, there were increased tensions and many conflicts between groups. This is common during the early periods of cultural assimilation; however, with the addition of cultural equality and flexibility, success of acculturation in the region between the pre-Islamic and Islamic cultures is demonstrated. This can be witnessed in the construction of the tombs. These new relationships inspired the creativity of the artists to create a new culture, without precedent. And as much as Islam influenced the local people, so too did they enrich local Islamic culture through continuity of the specific characteristics that are unique to the cultures of South and West Sulawesi.

\section{Acknowledgements}

The comments of two anonymous referees are gratefully acknowledged.

\section{Author biography}

Rosmawati Archaeology Department, Faculty of Law and Culture, Hasanuddin University, Makassar, South Sulawesi, Indonesia

\section{References}

Ambary, H.M. 1985. De l'animisme à l'Islam: Le témoignage de quelques monuments funéraires de la région de Bone. Archipel 29(1):165-173. doi.org/10.3406/arch.1985.2228 (accessed 5 June 2018).

Ambary, H.M. 1998. Menemukan Peradaban: Jejak Arkeologis dan Historis Islam Indonesia. Jakarta: Logos.

Andrews, R.G. and I.C. Glover. 1986. Ulu Leang 2, an Iron Age jar burial cave in South Sulawesi, Indonesia. Indonesia Circle 40:47-64. doi.org/10.1080/03062848608729639 (accessed 5 June 2018).

Bougas, W.A. 1998. Bantayan: An early Makassarese kingdom, 1200-1600 AD. Archipel 55(1):83-123. doi.org/10.3406/arch.1998.3444.

Bougas, W.A. 2007. Gold looted and excavated from late (1300 AD-1600 AD) pre-Islamic Makassar graves. Archipel 73(1):111-166. doi.org/arch_0044-8613_2007_num_73_1_3877 (accessed 5 June 2018). 
Bulbeck, F.D. 1992. A Tale of Two Kingdoms: The Historical Archaeology of Gowa and Tallok, South Sulawesi, Indonesia. Unpublished PhD thesis, School of Archaeology and Anthropology, The Australian National University, Canberra. www.oxis.org/theses/bulbeck-1992.pdf (accessed 5 June 2018).

Bulbeck, D. and I. Caldwell. 2000. Land of Iron: The Historical Archaeology of Luwu and the Cenrana Valley. Results of the Origin of Complex Society in South Sulawesi Project (OXIS). Hull: Centre for South-East Asian Studies, University of Hull. www.oxis.org/books/land-of-iron.pdf (accessed 5 June 2018).

Bulbeck, D., I. Caldwell., S. Druce, B. Hakim and C. Macknight. 2018. Imported tradeware ceramics and their relevance for dating socio-political developments in South Sulawesi, with special reference to the Allangkanangnge ri Latanete site. In S. O'Connor, D. Bulbeck and J. Meyer (eds), The Archaeology of Sulawesi: Current Research on the Pleistocene to the Historic Period, pp. 269-287. Canberra: ANU Press.

Caldwell, I.A. and M. Nur. 2005. Three locally-made bronzes from South Sulawesi: Possible evidence of cultural transfer from Java about AD 1000. Review of Indonesian and Malaysian Affairs 39(1):23-34. www.oxis.org/downloads/caldwell-and-nur.pdf (accessed 5 June 2018).

Chamshi-Pasha, L. 2008. A Study of the Islamisation of South Sulawesi through an Analysis of the Grave of the second Muslim Ruler of Luwuq. Honours thesis. www.oxis.org/theses/chamsi-pasha.pdf (accessed 5 June 2018).

Djajadiningrat, R.A.H. 1911. Critisch overzicht van de in Maleische werken vervatte gegevens over de geschiedenis van het Sultanat van Atjeh. Bijdragen tot de Taal-, Land-en Volkenkunde 65:135-260. doi.org/10.1163/22134379-90001836 (accessed 5 June 2018).

Duli, A., Rosmawati and Muhaeminah. 2013. Makam. In A. Duli, A. Rahman, B. Sulistyanto, Muhaeminah, Roadah, Rosmawati and Y. Sumalyo (eds), Monumen Islam di Sulawesi Selatan, pp. 109-242. Makassar: Balai Cagar Budaya Makassar. books.google.com.au/books?id=ZKtrCAAAQBAJ\&printsec=frontcover $\& \mathrm{dq}=$ Monumen + Islam $+\mathrm{di}+$ Sulawesi+Selatan\&hl=en\&sa=X\&ved=0ahUKEwirmtqchqneAhVjz1QKH dTRD9UQ6AEIKDAA\#v=onepage \&q=Monumen\%20Islam\%20di\%20Sulawesi\%20Selatan \&f=false (accessed 27 October 2018).

Fakhri. 2016. Situs Rampi: Masa persebaran arca batu dan hubungannya dengan di wilayah situs terdekat [Rampi sites: The dispersion age of stone statue and the connection between nearest site areas]. Walennae 14(1):23-36. walennae.kemdikbud.go.id/index.php/walennae/article/view/38 (accessed 27 October 2018).

Flavel, A. 1997. Sa-Huynh Kalanay? Analysis of the Prehistoric Decorated Earthenware of South Sulawesi in an Island Southeast Asian Context. Unpublished BSc (Hons) thesis, Centre for Prehistory, University of Western Australia, Perth.

Hasanuddin. 2015. Kebudayaan Megalitik di Sulawesi Selatan dan Hubungannya dengan Asia Tenggara. Unpublished PhD thesis, Centre for Archaeological Research Malaysia, Universiti Sains Malaysia, Kuala Lumpur. www.oxis.org/theses/hasanuddin-2015.pdf (accessed 5 June 2018).

Kallupa, B., D. Bulbeck, I. Caldwell, I. Sumantri and K. Demmanari. 1989. Survey Pusat Kerajaan Soppeng 1100-1986 [Survey of the Capital of Soppeng Kingdom 1100-1980. Final Report to the Australian Myer Foundation, Privately published in Canberra, ACT. www.oxis.org/books/soppeng-1986.pdf (accessed 5 June 2018).

Makkullasse, A.H. 1986. Laporan Pengumpulan Data 'Peninggalan Sejarah dan Purbakala' Kabupaten Enrekang. Ujung Pandang [Makassar]: Suaka Peninggalan Sejarah dan Purbakala Sulawesi Selatan.

Marioga, N. 1995. Makam Raja-Raja Kutai Kertanegara di Tenggarong Kabupaten Kutai Propinsi Kalimantan Timur. Unpublished B.A. (Hons) thesis, Jurusan Arkeologi, Fakultas Sastra, Universitas Hasanuddin, Makassar.

Masdoeki. 1984. Laporan Pengumpulan Data Peninggalan Sejarah dan Purbakala di Kabupaten Barru. Ujung Pandang [Makassar]: Suaka Peninggalan Sejarah dan Purbakala Sulawesi Selatan. 
Masdoeki. 1985a. Laporan Pengumpulan Data Peninggalan Sejarah dan Purbakala di Kabupaten Takalar. Ujung Pandang [Makassar]: Suaka Peninggalan Sejarah dan Purbakala Sulawesi Selatan.

Masdoeki. 1985b. Laporan Pengumpulan Data Peninggalan Sejarah di Kotamadia Ujung Pandang. Ujung Pandang [Makassar]: Suaka Peninggalan Sejarah dan Purbakala Sulawesi Selatan.

McWilliam, A., F.D. Bulbeck, S. Brockwell and S. O'Connor. 2012. The cultural legacy of Makassar stone in East Timor. The Asia Pacific Journal of Anthropology 13(3):262-279. doi.org/10.1080/14442213.20 12.674054 (accessed 5 June 2018).

Muttalib, M.A. 1980. Naskah Studi Kelaykan: Makam La Tenri Ruwa (Raja Bone ke XI) Bantaeng, Sulawesi Selatan. Ujung Pandang [Makassar]: Proyek Pemuguran dan Pemeliharaan Peninggalan Sejarah dan Purbakala Sulawesi Selatan.

Muttalib, M.A. 1984. Taman Purbakala Jera Lompoe. Ujung Pandang [Makassar]: Suaka Peninggalan Sejarah dan Purbakala Sulawesi Selatan.

Noorduyn, J. 1987. Bima en Sumbawa: Bijdragen tot de Geschiedenis van de Sultanen Bima en Sumbawa door A. Ligtvoet en G.P. Rouffaer. Dordrecht: Foris Publications.

Oktaviana, A.A., D. Bulbeck, S. O’Connor, B. Hakim, Suryatman, U.P. Wibowo, E. St Pierre and Fakhri. 2016. Hand stencils with and without narrowed fingers at two new rock art sites in Sulawesi, Indonesia. Rock Art Research 33(1):32-48.

Othman, M.Y. 1988. Batu Aceh : Early Islamic Gravestones in Peninsular Malaysia. Kuala Lumpur: Museum Association of Malaysia.

Pelras, C. 1985. Religion, tradition and the dynamics of Islamization in South Sulawesi. Archipel 29:107135. doi.org/10.3406/arch.1985.2226 (accessed 5 June 2018).

Perret, D. and K.A. Razak. 1999. Batu Aceh Warisan Sejarah Johor. Selangor: Yayasan Warisan Johor.

Ricklefs, M.C. 2008. A History of Modern Indonesia since c. 1200. London: Palgrave MacMillan.

Santosa, H.B. 1980. Catatan Tentang Perbandingan Nisan dari beberapa Daerah di Indonesia. Jakarta: Pusat Penelitian Arkeologi Nasional.

Sulistyo, B. 2013. Islamisasi dan persemaian budaya lokal di Sulawesi Selatan. In A. Duli, A. Rahman, B. Sulistyanto, Muhaeminah, Roadah, Rosmawati and Y. Sumalyo (eds), Monumen Islam di Sulawesi Selatan, pp. 3-33. Makassar: Balai Cagar Budaya Makassar. books.google.com.au/books?id=ZKtrCAA AQBAJ\&printsec=frontcover\&dq=Monumen+Islam $+\mathrm{di}+$ Sulawesi + Selatan\&hl=en\&sa=X\&ved=0ahUK EwirmtqchqneAhVjz1QKHdTRD9UQ6AEIKDAA\#v=onepage\&q=Monumen\%20Islam\%20di\%20 Sulawesi\%20Selatan\&f=false (accessed 27 October 2018).

Sumantri, I. 1996. Pola Pemukiman Gua-Gua Prasejarah di Biraeng Pangkep, Sulaswesi Selatan. Unpublished MA thesis, Program Studi Arkeologi, University of Indonesia, Jakarta.

Suriada M. and I. Abbas. 2003. Sejarah Islam di Sulawesi Selatan. Makassar: Masogena Press.

Tjandrasamita, U. 2000. Penelitian Arkeologi Islam di Indonesia dar Masa ke Masa. Kudus: Menara Kudus.

Tjandrasamita, U. 2009. Arkeologi Islam di Nusantara (ed. T. Hartimah, A. Chair, Testriono, O. Dahuri and S. Sulaiman). Jakarta: Kepustakaan Populer Gramedia.

Trip Advisor. 2017. Makam Karaeng Parang Parang - Picture of Tallo Kings Cemetery Complex, Makassar. www.tripadvisor.com.au/LocationPhotoDirectLink-g297720-d6538788-i140267287-Tallo_Kings_ Cemetery_Complex-Makassar_South_Sulawesi_Sulawesi.html (accessed 14 January 2017).

van der Hoop, A.N.J. 1941. Catalogus der Praehistorische Verzameling. Bandung: A.C. Nix \& Co. 
van Heekeren, H.R. 1950. De urnenfelden lesung batu en monolithen boven Somph nabij Sengkang, Zuid-Celebes. Oudheidkundig Verslag 1949, pp. 17-18. Bandung: A.C. Nix \& Co.

van Romondt, V.R. 1985. Makam-makam Islam di Sulawesi Selatan. Amerta 1:49-53.

Vink, J.J. de. 1912. Uittreksel uit het verslag over de oudheidkundige werkzaamheden in Pasé. Oudheidkundig Verslag 1912, pp. 53-56. Batavia [Jakarta]: Oudheidkundige Dienst in Nederlandsch-Indië. archive.org/ stream/in.ernet.dli.2015.530217/2015.530217.oudheidkundig-verslag_djvu.txt (accessed 5 June 2018).

\section{Appendix A: Typology of ancient tombs and gravestones in South Sulawesi}

To facilitate the description and classification of the grave and headstone styles, they can be classified according to the form, size and variety of their ornamentation. The creation of arbitrary labels for the different types provides a shorthand for their unambiguous referencing (Othman 1988), as in the main text here, where the overlapping chronology of the various types is also addressed. The typology presented here is an extension of the less comprehensive typology developed by Duli et al. (2013).

\section{Graves}

In order to produce a viable descriptive sequence, the graves are classified into styles based on their manufacturing technology and tomb shape in the following subsections. Photographs and drawings of each type (with the exception of Type I and Type L, illustrations of which are presented immediately after their description) are given as examples in Figure A19.3 at the end of this section.

\section{Type A}

The dome-covered style (Type A) consists of a square-footed tomb covered by a dome crowned at the summit with various headstone forms such as cudgels, bubbles, prisms and lotus flowers. The tomb is constructed with brickwork or andesite blocks and plastered with a mixture of sand and lime. There is an entrance on one side from which to view the several graves contained within the tomb. These tombs include both decorated and undecorated examples. The dome shapes vary from semicircular to oval and pyramidal, and there are both large and small examples. The domecovered style is found at the grave complexes of Kale Gowa (Katangka, Syech Yusuf, Sultan Hasanuddin and Bonto Biraeng), Tinggi Maek near Kale Gowa, the royal Sanrabone cemetery complex in Sanrabone fortress (Bulbeck 1992), Tallok, Lala Bata Watampone (Bone), Lokkoe Palopo and several cemeteries in Barru District. This form of tomb has existed since the mid-17th century in South Sulawesi.

\section{Type B}

This style (Type B) has stepped terraces above a rectangular chamber with a single entrance opening on to several graves. The stepped terraces, which are similar to Type D, are made of stacked andesite blocks and have a receding profile. On the topmost level, there are one or two gravestones, sometimes decorated with a variety of motifs. The terraces can have three, five or seven levels. This style of tomb is found in the cemetery complexes of Sultan Hasanuddin, Tallok, Lamuru (interior Bone District), Lokkoe Palopo, Latenri Ruwa (Bantaeng) and in Barru. Its inception and subsequent period of expansion date back to the early 17th century, coinciding with the entry of Islam into South Sulawesi. 
Type C

This is a style with a cover shaped like a traditional house (Type C); that is, the top resembles the peaked roofs commonly seen in Indonesian houses. It is built from an arrangement of unworked stones, stone slabs, bricks or timber. The orientation is oblong, the summit consists of a stone replica of a saddled or pyramidal roof, and sometimes the tomb is decorated. On one side, there is an entrance to the interior where several graves are present. This type of tomb is found in the cemetery complexes of Tallok, Katangka, Latenri Ruwa, Barru, Majene, Enrekang and Lokkoe Palopo.

\section{Type D}

The stepped terrace style (Type D) is a type of tomb with an undulating outline constructed from a stacked arrangement of stone slabs, unworked stones or bricks. There are between one and five terraces, which may be decorated or plain. The topmost terrace has one or two gravestones, with many variations in their form and dimensions. This type of tomb is found in almost every major cemetery complex in South and West Sulawesi.

\section{Type E}

The boat-shaped style (Type E) is built to have the appearance of a boat, consisting of a base, a body and a crowning platform with one or two gravestones. This type of grave is built from stacked stone slabs. It is found in several cemetery complexes in Bulukumba, Enrekang, Barru and Majene. This is also the form of graves documented in the Fataluku-speaking parts of East Timor, where it is referred to as 'Makassar stone'. A similar style was employed for the grave at Tallok of Karaeng Katinting (Table 19.2), brother of the Tallok sultan Mudhaffar Tumammaliang ri Timorok who undertook a successful military expedition to Timor in 1641 (McWilliam et al. 2012).

\section{Type $F$}

The candi style (Type F) is a type of tomb shaped like a Hindu/Buddhist temple, consisting of a base, a body and a summit, constructed from a stacked arrangement of non-masoned stones and stone slabs. This style is square at its base with stacked levels and has one gravestone at the summit. Otherwise, it is variable in its form and dimensions. This type of tomb can be seen in various cemetery complexes in Barru, Bulukumba, Enrekang, Malangke and Majene.

\section{Type $G$}

The box style (Type $G$ ) is a type of grave shaped like a box or quadrangle, with the same dimensions at its base and its top. It also presents vertical walls that peak at the north and south facings. These tombs are constructed from a stacked arrangement of unworked stones and masonry blocks. There can be one or two gravestones on top of variable dimensions. This type of grave is found in in Jeneponto, Bantaeng, Bulukumba, Enrekang and Majene. Box graves are also common in cemeteries across the Makassar hinterland (Bulbeck 1992).

\section{Type $H$}

Monoliths (Type $\mathrm{H}$ ) are a type of grave shaped from a single block of quarried stone, including the base, the body and the gravestone components. While the shape and dimensions of these graves vary, they are generally small, and are found in Jeneponto and Majene.

\section{Type I}

The wooden variety (Type I) is a grave and gravestones made of certain types of wood such as teak, ironwood and ebony. Usually these graves are richly decorated (Figure A19.1). They are found in various cemetery complexes including Tosora (Wajo), Bone, Barru and Majene. 


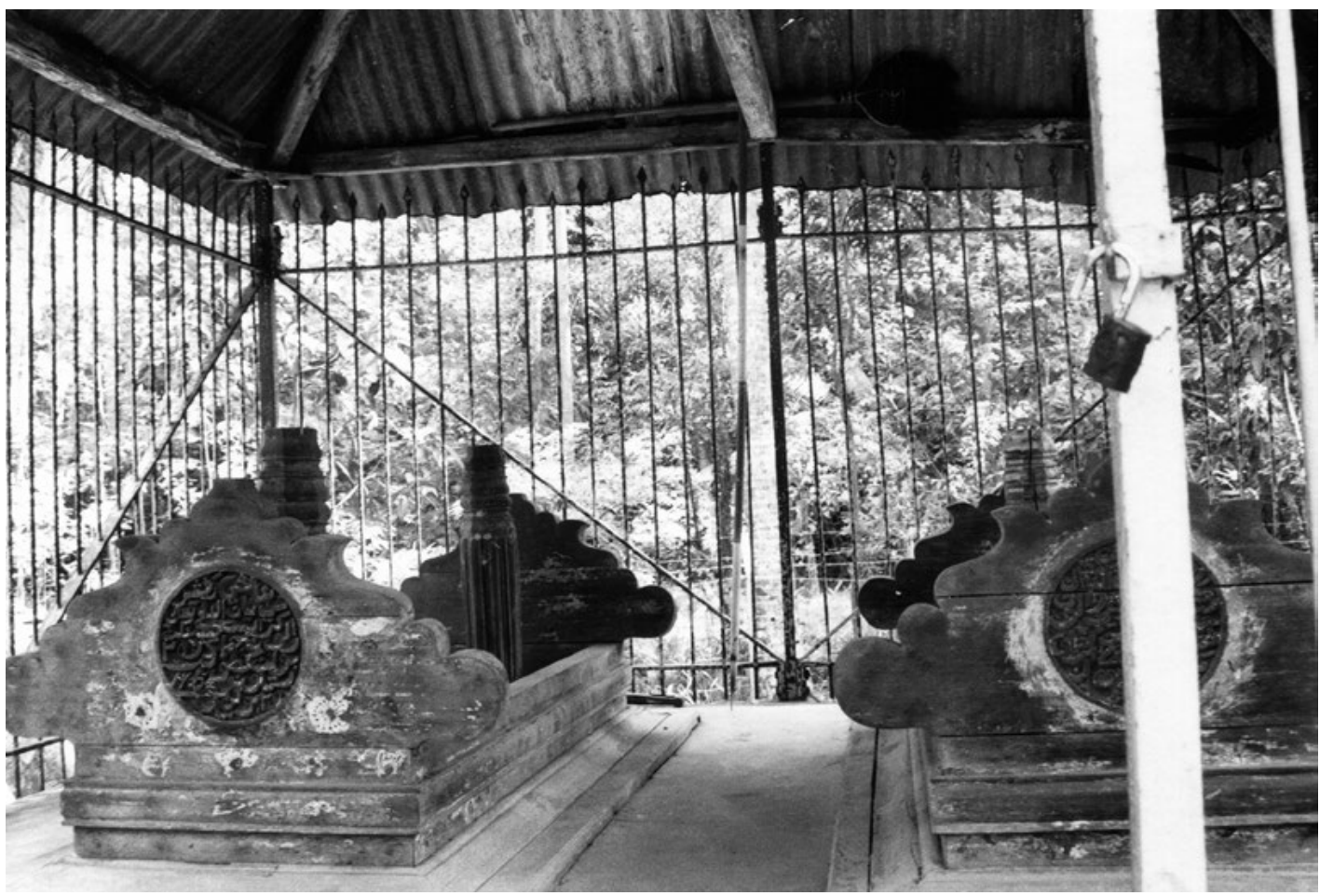

Figure A19.1: Wooden grave and gravestones (Type I) at Makam Karaengta Bungaya, Taeng, locally associated with Karaeng Bungaya who died in 1640.

Source: Bulbeck (1992:Photo 7-38).

\section{Type J}

The standard grave style (Type J) is a grave constructed like a basin, built from unworked stones or stone blocks arranged into a parapet. Sometimes the basin shape peaks at the north and the south, some sort of ornamentation is usual, and there are one or two gravestones inserted at the end(s). This type of grave is found in almost all of the old cemetery complexes of South and West Sulawesi.

\section{Type $K$}

The heaped stone mound (Type $\mathrm{K}$ ) is a tomb made just from a mound of heaped nonmasoned stones, mounded or tapering towards the top, where there are one or two gravestones. This style is found in Sinjai, Soppeng, Barru, Enrekang and Majene.

\section{Type L}

The heaped earth mound (Type L) is a tomb made just from a mound of heaped earth, with one or two gravestones on top (Figure A19.2). This type of grave is found in almost all the old cemetery complexes of South and West Sulawesi.

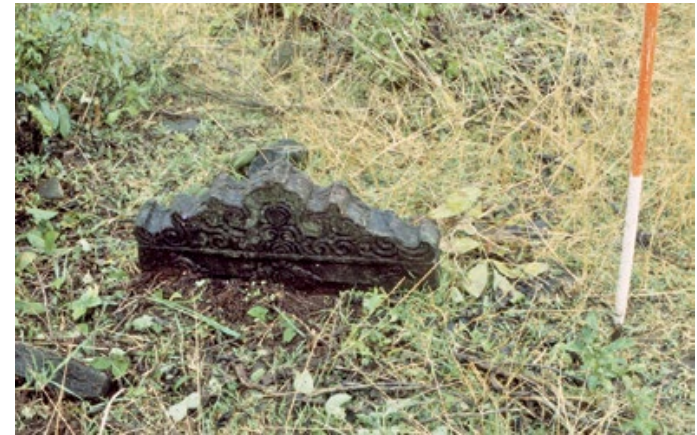

Figure A19.2: Heaped earth mound grave with crenulated masonry gravestone (Type L) at Kuburan Islam Bontona Songkolo, upstream from Kale Gowa, reportedly associated with a local elite. Source: Bulbeck (1992:Photo 9-38). 


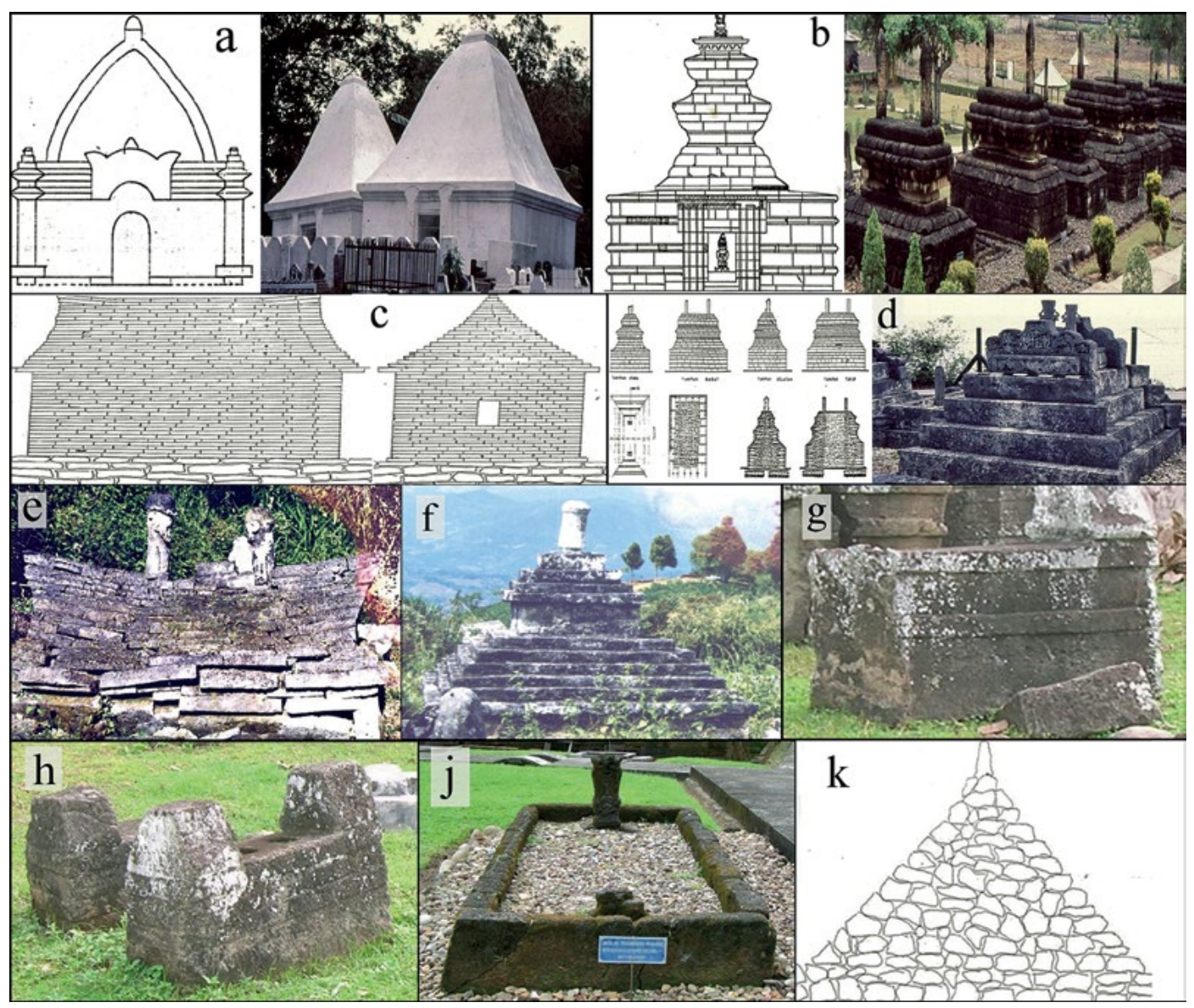

Figure A19.3: Tomb styles in South Sulawesi Islamic cemeteries.

(a) Type A - the dome-covered style, Sultan Hasanuddin complex (left), Katangka (right), Kale Gowa; (b) Type B - style covered with a stepped terrace, Kale Gowa (left), Lamuru (right); (c) Type C - style with a cover shaped like a traditional house, Makam Tandijalling; (d) Type D - stepped terrace style, La Tenri Ruwa (left), Jera Lompoe (right); (e) Type E - boat-shaped style, Makam Laiya; (f) Type F- candi style, Makam Laiya; (g) Type G - box style, Binamu royal cemetery; (h) Type H - monoliths, Binamu royal cemetery; (j) Type J - standard grave style, Jera Lompoe; (k) Type $\mathrm{K}$ - heaped stone mound (schematic representation).

Sources: Duli et al. (2013); Rosmawati field notes.

\section{Gravestones}

The author's classification and typology of gravestones is based on similar work by previous experts. It is apparent that the early Islamic types found in South and West Sulawesi are in many cases also found in Sumatra, the Malay Peninsula and Java, and so we can follow the gravestone classificatory systems of Othman Mohd. Yatim and Hasan Muarif Ambary. Ambary (1998:45) classified the Indonesian Archipelago gravestones under the Aceh, Demak (Troloyo), TernateTidore and Bugis-Makasar types. The Aceh type has been associated with the expansion of Islam in the Indo-Malaysian Archipelago by Othman (1988). He divided the type into 13 styles using an alphabetical coding system $(A, B, C, D, E, F, G, H, J, K, L, M$ and $N)$, which were supplemented by the $O, P$ and $Q$ styles by Perret and Razak (1999). In South and West Sulawesi, the Aceh type is common in cemeteries that were founded during the early 17th century when Islam originated in South Sulawesi, and later cemeteries associated with the increasing spread of Islam-cemeteries such as the Sultan Hasanuddin complex in Gowa, the Tallok rulers' complex in Makassar, the Binamu rulers' complex in Jeneponto, the Latenri Ruwa complex in Bantaeng, the Lamuru rulers' complex in Bone, Lokkoe Palopo in Luwu and the Majene aristocrats' cemetery in West Sulawesi. 
The Demak (Troloyo) gravestone type includes characteristic influences from Majapahit in the forms of medallions, kalamakara decorations, lotuses, water-lily tendrils and other classical designs, such as Javanese inscriptions in the Jawa script and tridents. They accompany many 18th-century graves in South and West Sulawesi, probably due to the influence of Eastern Javanese Islamic mysticism (Ricklefs 2008:60) on Sulawesi at the time. The (local) Ternate-Tidore type is characterised by gravestones with the head shaped like a pineapple and Malay inscriptions using the Arabic script, but these are rare in South Sulawesi, except at the Katangka cemetery complex (Kale Gowa). The Bugis-Makasar type is the dominant local type and is rich in floral and anthropomorphic designs, as well as megalithic forms such as statuesque gravestones, kris handles and sculptures of lontaraq (Bugis-Makasar script) and Arabic letters, with considerable local variation within this general type. The Bugis-Makasar type is also found in southern Thailand, Brunei and southern Philippines (Ambary 1998:95-104).

The classification applied in this composition is based on the work of previously mentioned experts. The label $A$ refers to the Aceh gravestone type, or specifically $A A$. The Demak (Troloyo) type is given the label $B$ and the Ternate-Tidore is codified as Type $C$. Type $D$ is used for the other style types which flourished in the districts of South Sulawesi. This chapter classifies the local South Sulawesi styles within Type $D$, expanding this type with sequential numbering. For instance, the Bugis-Makasar Type 1 becomes $D 1$ and so on $(D 2, D 3 \ldots)$.

The various styles of Bugis-Makasar gravestones that occur across South Sulawesi are contained in the following subsections. Figure A19.5 at the end of this subsection represents the styles previously mentioned as well as many of those described below.

\section{Type D1}

The kris handle style (Type D1) is shaped like the handle of a kris dagger with some variety in the form, dimensions and decorations and is made from stone or wood. This style is found in the cemetery complexes of Tallok, Binamu, Latenri Ruwa, Jera Lompoe, Tosora, Lamuru, Barru, Allakkuang and Majene.

\section{Type D2}

The human figurine style (Type D2) includes anthropomorphic gravestones made of stone whether complex or simple (usually just the head with the eyes, mouth and ears). This style of gravestone is found in the cemetery complexes of Binamu, Latenri Ruwa, some graveyards in the areas of Balusu and Mallusetasi in Barru, Enrekang and Majene.

\section{Type D3}

The sword style (Type D3) is a gravestone with a sword in relief and a channel along its midline, or that is shaped like a sword handle. It is made of stone and can be found in most of the old graveyards of South and West Sulawesi.

\section{Type D4}

The spear-tip style (Type D4) is shaped like the triangular tip of a spear and is made from stone or wood. It is found in most of the old graveyards of South and West Sulawesi.

\section{Type D5}

The Bugis songkok style (Type D5) is shaped like a Bugis songkok hat, with a cylindrical form and vertical decorative lines. It is made from stone and found in the old cemetery complexes of Wajo, Bone, Sinjai and Soppeng. 


\section{Type D6}

The half-sphere style (Type D6) has the shape of a semi-sphere and is sometimes accompanied by vertical decorative lines. It is found in various old cemeteries in Wajo such as the Tosora complex.

\section{Type D7}

The crown style (Type D7) is shaped like a crown and is made of stone. It is embellished with various designs on four or eight sides. It is found in almost all of the old cemetery complexes of South and West Sulawesi.

\section{Type D8}

The block style (Type D8) is made from a single block, and has four identical components and a summit that can be flat, rounded, oval or prismatic. It is made from stone or wood, and can be found in most of the old cemetery complexes of South and West Sulawesi.

\section{Type D9}

The cylindrical style (Type D9) has six or eight sides and a peak that can be rounded, oval or prismatic. It is made from stone or wood, and is found in almost all of the old cemetery complexes of South and West Sulawesi.

\section{Type D10}

The cudgel style (Type D10) has a tapering rounded shape and is created from masoned stone with varying degrees of preliminary preparation. It can be found in most of the old cemetery complexes of South and West Sulawesi.

\section{Type D11}

The phallic style (Type D11) is the gravestone formed like a penis (phallus). It is made from stone or wood and found in most of the old cemetery complexes of South and West Sulawesi.

\section{Type D12}

The menhir style (Type D12) is a menhirshaped gravestone made from non-masoned stone, whether with prior shaping or not, thin or rounded, and found in almost all of the old cemetery complexes of South and West Sulawesi.

\section{Type D13}

The cannon style (Type D13) sometimes consists of the rear part of a cannon or is made in a similar shape from stone or wood. It can be found in the cemetery complexes of Tosora, Majene, Enrekang and Barru.

\section{Type D14}

The iron helmet style (Type D14) resembles the type of helmet that was used in the army. It is made from stone, and can be found at Tosora and in Enrekang and Majene.

\section{Type D15}

The tempayan style (Type D15) consists of a large storage jar that is either a high-fired imported ceramic jar from China or a local product made from earthenware. This style is found in Kale Gowa (Figure A19.4), Soppeng, Wajo, Bone and Sinjai.

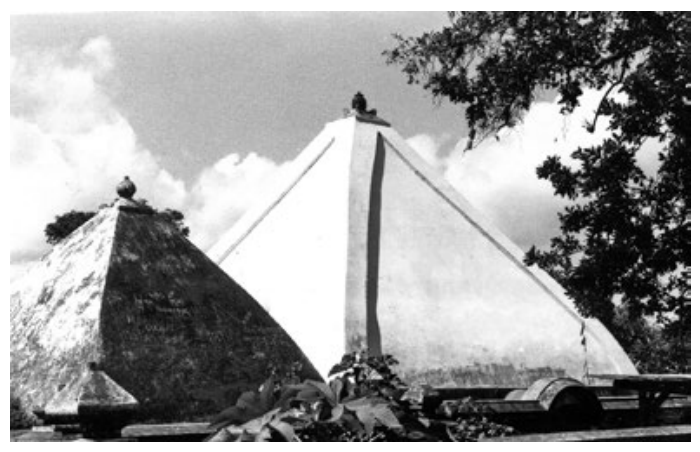

Figure A19.4: Stoneware jar placed on top of the dome-covered tomb of Syech Yusuf, who was buried at Kale Gowa in 1705.

Source: Bulbeck (1992:Photo 6-25). 

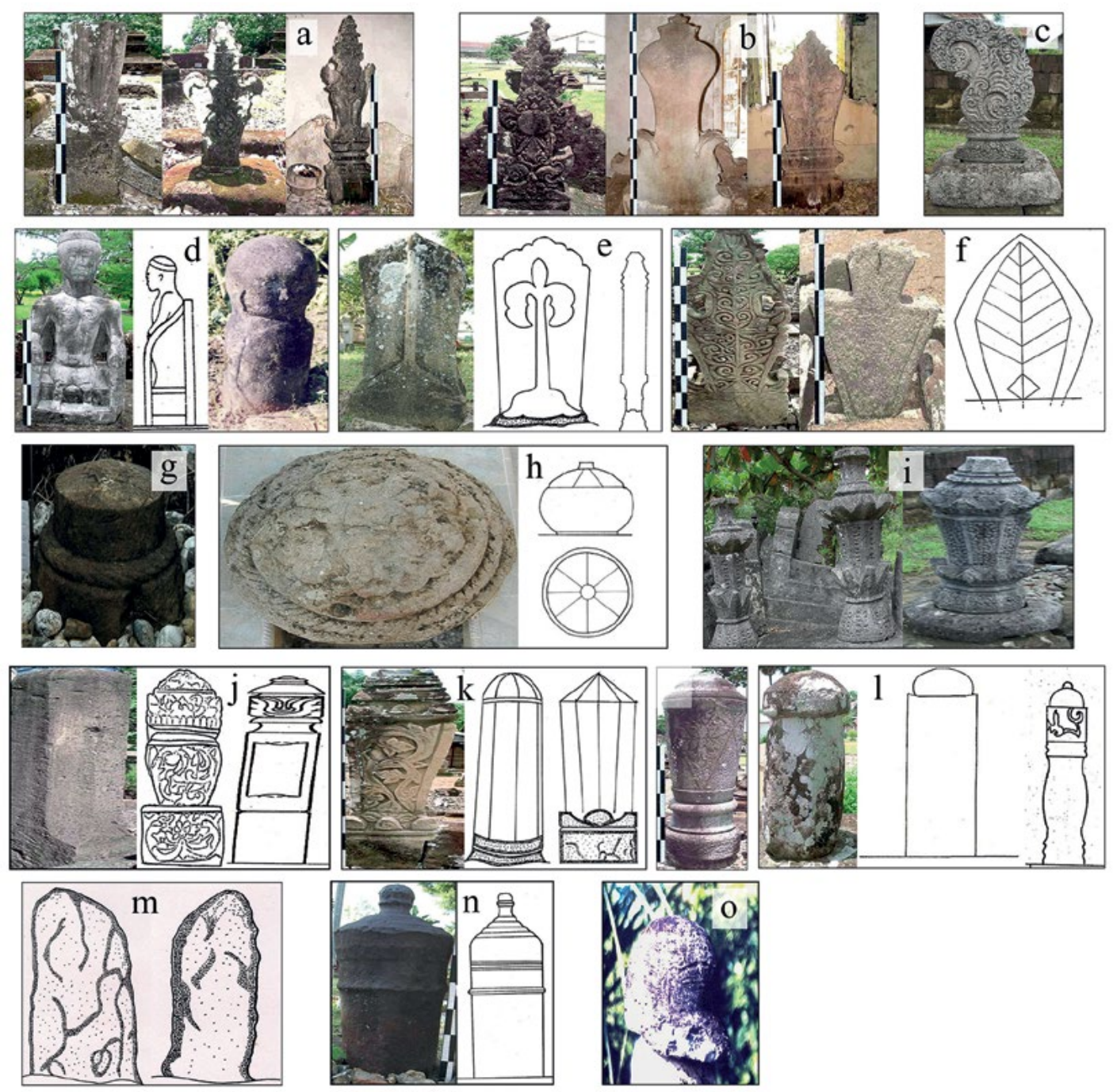

Figure A19.5: Gravestone types in South Sulawesi Islamic cemeteries.

(a) Aceh type in the Tallok cemetery complex; (b) Demak-Troloyo type in the Tallok cemetery complex; (c) Type D1 - kris handle style, Jera Lompoe; (d) Type D2 - human figurine style, Binamu royal cemetery (left and centre) and Makam Laiya, Enrekang (right); (e) Type D3 - sword style, Jera Lompoe (left), Makam Nagauleng (right); (f) Type D3 - sword style, Binamu (left), Takalar (centre), Type D4 - spear-tip style, Tosora (right); (g) Type D5 - Bugis songkok style, Tosora; (h) Type D6 - half-sphere style, Tosora; (i) Type D7 - crown style, Majene (left), Binamu (right); (j) Type D8 - block style, Makam Dea Daeng Lita (left), Binamu (centre), Tosora (right); (k) Type D9 - cylindrical style, Wajo (left and centre), Kale Gowa (right); between k and I) Type D10 - cudgel style, Takalar; (I) Type D11 - phallic style, Binamu (left), Makam Dae Daeng Lita (centre), unidentified cemetery (right); (m) Type D12 - menhir style, Tosora; (n) Type D13 - cannon style, Tosora (left), Wajo (right); (0) Type D14 - iron helmet style, Laiya.

Sources: Duli et al. (2013); Rosmawati field notes. 
This text is taken from The Archaeology of Sulawesi: Current Research on the Pleistocene to the Historic Period, edited by Sue O'Connor, David Bulbeck and Juliet Meyer, published 2018 by ANU Press, The Australian National University, Canberra, Australia.

doi.org/10.22459/TA48.11.2018.19 